\title{
Cover Crop, Reflective Polyethylene Mulch and Biofungicide Effects on Yield and Management of Diseases in Field-Grown Organic Tomato
}

\author{
Leopold M. Nyochembeng ${ }^{1}$, Regine N. Mankolo ${ }^{1}$, Srinivasa R. Mentreddy ${ }^{1} \&$ Guru Mayalagu $^{1}$ \\ ${ }^{1}$ Department of Biological \& Environmental Sciences, Alabama A\&M University, Normal, AL, United States \\ Correspondence: Leopold M. Nyochembeng, Alabama A\&M University, Department of Biological \& \\ Environmental Sciences, 4900 Meridian Street, P.O. Box 1208, Normal, AL 35762, United States. Tel: \\ 1-256-372-4218. E-mail: leopold.nyochembeng@aamu.edu
}

Received: July 2, 2014 Accepted: September 25, 2014 Online Published: November 15, 2014

doi:10.5539/jas.v6n12p265 URL: http://dx.doi.org/10.5539/jas.v6n12p265

\begin{abstract}
Organic farming is currently the fastest growing agricultural sector worldwide. However, diseases and weeds are among the major factors limiting its expansion. The use of cover crops has been shown to reduce weeds and minimize soil-borne pathogen populations through increased organic matter deposition, which also improves soil structure and porosity. Reflective and colored plastic mulches have also been shown to reduce vector borne diseases on many vegetable crops, including tomato. Such measures to combat disease depend on other variables and are generally site-specific. Two experiments were conducted to evaluate the effects of the winter cover crops, crimson clover, rye, hairy vetch, and Austrian winter peas and reflective polyethylene mulch with or without biofungicides on severity of diseases and fruit yield of tomato. Plant height, fruit weight, number of fruits per plant and the type of foliar and fruit diseases observed including their severity were determined. Tomato fruit rot incidence was significantly lower in tomato plants grown following hairy vetch and Austrian winter pea compared to plants in fallow plots. Reflective polyethylene mulch was significantly $(\mathrm{p}=5 \%)$ better than control (no mulch) for fruit yield, number of fruits/plant and plant height. However, plants on reflective polyethylene mulch showed significantly more severe bacterial spot disease. Application of spent mushroom compost under polyethylene mulch significantly enhanced tomato fruit yield and number of fruits/plant compared to the biofungicide Root Guardian ${ }^{\circledR}$, but increased bacterial spot severity compared to Plant Guardian ${ }^{\circledR}$. The results of this study indicated that winter cover crops enhance yields of tomato by minimizing disease while reflective polyethylene mulch and spent mushroom compost are conducive to growth and fruit yield in field-grown organic tomato.
\end{abstract}

Keywords: biopesticide, cover crop, organic farming, plastic mulch, spent mushroom substrate

\section{Introduction}

Organic crop production has gained significant popularity among both consumers and producers in recent years due to health benefits, cash premiums and positive environmental impacts. In the U.S., over 1.2 million hectares of land is used for organic agriculture (Campiglia, Paolini, Colla, \& Mancinelli, 2009; Willer, 2008). Plant disease management in organic vegetable production presents an economic challenge for small farm owners especially in the hot humid summer months. Due to exclusion of synthetic pesticide use in this production system, effective strategies are needed to mitigate resurgent diseases which could become a major production constraint for the small organic vegetable grower. Plant disease management in this production system also needs to be integrated and multifaceted in order to be effective. Such disease management tactics should be easily adaptable to small farm production environment and should be tailored to long-term farm sustainability. Among strategies for mitigating diseases and epidemics is incorporation of cover crops in rotations to break disease cycles (Baldwin \& Creamer, 2006). While cover crop effects on disease in organic production systems could be variable and site specific, the improvement in soil structure and porosity has been shown to minimize soil-borne pathogens (Widmer, Mitkowski, \& Abawi, 2002). Insect vectors, particularly thrips that spread diseases in tomato, are known to identify host plants by color, shape, size, and floral volatiles. Researchers have reported that highly UV reflective surfaces in the 350-390nm range repel thrips (Kelley, 2009). Silver colored plastic mulch effectively does this and will reduce thrips (Kelley, 2009). Additionally, biofungicides and organic mulches such as spent mushroom compost are known to not only reduce diseases but also enhance plant growth 
and fruit quality of tomato (Nyochembeng, Mankolo, \& Mentreddy, 2010).

Cover crops have several beneficial effects such as breaking disease cycles, suppressing weeds and improving soil nutrients in addition to reducing soil erosion and improving soil quality. Specific studies have shown that cover crops may boost the management of soilborne pathogens (Larkin, Griffin, \& Honeycutt, 2006), remove residual nitrate $\left(\mathrm{NO}_{3}{ }^{-}\right)$available to leaching, and control root diseases and weeds (Dabney, Delgado, \& Reeves, 2001; Sainju, Whitehead, \& Singh, 2005). Compared to conventional cropping systems, crop rotations with cover crops have resulted in greater macrofaunal and microbial activity (Mendes, Bandick, Dick, \& Bottomley, 1999) which enhance soil health. Other researchers have found that cover crop residues function as a source of soil C and N (Kuo et al., 1997) and concomitantly mineralize to provide the amount of $\mathrm{N}$ required for plant growth (Reeves, 1997). Some cover crops (hairy vetch) can cause an increase in population of soil pathogens (Rhizoctonia spp., Pythium spp.) but not disease progression (Rothrock, Kirkpatrick, Frans, \& Scott, 1995). It was also observed that despite an increase in soil population of Rhizoctonia spp. and Pythium spp. following hairy vetch compared to winter fallow, no increase in disease and insect pest problems occurred due to cover cropping with winter rye in a subsequent broccoli crop (Wyland et al., 1996). In spite of the significant value of cover crops to organic production, there is limited research-based information on the relative efficacy of various winter cover crops for pest and plant disease management in organic vegetable production in southeastern USA.

Application of composts and treatment of plants with resistance inducing agents and disease suppressing microbial organisms such as Trichoderma sp., Bacillus sp. and other organisms is foremost in the biological control of many diseases and has helped minimize crop losses due to disease (Ezziyyani, Requena, Egea-Gilbert, \& Candela, 2007; Jacobsen, Zidack, \& Larson, 2004; Zehnder, Murphy, Sikora, \& Kloepper, 2001).

Current sustainable disease control practices by small growers involve the use of colored and reflective polyethylene mulches. Owing to their humidity lowering effect, these soil bed covers have been suggested as a means to minimize the development of some foliar diseases such as gray mold (Elad, 2000). Polyethylene mulch modifies the microclimate of the soil beneath it and of the atmosphere above it (Tarara, 2000). Mulching with polyethylene is hypothesized to create conditions within the plant canopy which are less favorable to disease development (Shtienberg et al., 2010). UV-reflective metal coated plastic mulches are increasingly being tested to ward off insect pests and insect vectors of many viral diseases including tomato spotted wilt virus. Recently, Murphy et al. (2009) observed that reflective plastic mulch reduced watermelon mosaic virus incidence and yield losses in squash. Combining reflective plastic mulch and biofungicides application could provide a wholesome approach to managing weeds, insect pests including those that vector plant viruses and other plant diseases in small organic vegetable production systems. Two separate experiments were conducted over two growing seasons to evaluate cover crops, polyethylene soil bed covers and biofungicides for managing diseases in tomato. The objective of experiment 1 was to evaluate the effects of winter cover crops (crimson clover, rye, hairy vetch, and Austrian winter peas) on weed biomass, tomato diseases and fruit yield, while in experiment 2 we assessed the effects of polyethylene mulch in combination with biofungicides, both on the incidence and severity of common tomato diseases and fruit yield in organic production system.

\section{Materials and Methods}

\subsection{Experimental Site}

The experiments were conducted in 2008 and 2009 on Decatur silty clay loam (Clayey, Kaolinitic, Thermic Rhodic Paleudults) at Winfred Thomas Agricultural Research Station (WTARS) of Alabama A \& M University in Hazel Green, Alabama $\left(34^{\circ} \mathrm{N} 56,86^{\circ} \mathrm{W} 34\right)$, on a 6 -acre block of land used exclusively for organic production research. Monthly rainfall, daily mean temperature and relative humidity were recorded at the experiment site. In 2006, the six-acre block was divided into four sub-blocks called rotation plots. Each year, fall cover crops such as crimson clover, rye, hairy vetch, Austrian winter peas, and control with no-cover crop treatments were established. In the following summer, cash crops such as tomato, pepper, purple hull peas, and sweet corn were planted to evaluate their response to cover crop. Summer cover crops such as iron clay peas and Sudan $x$ sorghum hybrid mix, velvet bean, sunflower, sun hemp, and Japanese millet were planted in plots not planted with summer cash crops. In this study only tomato cv 'Amelia' was evaluated.

\subsection{Land Preparation, Planting and Application of Treatments}

An area of fallow land (used for hay production for more than 10 years) and measuring $30 \mathrm{~m} \times 60 \mathrm{~m}$ was tilled with a disc plough and partitioned into 5 plots each $12 \mathrm{~m}$ long and $3.6 \mathrm{~m}$ wide. Due to the low $\mathrm{pH}(5.2)$ of this soil, the plots were treated with lime (rock calcium at a rate of $5380 \mathrm{~kg} / \mathrm{ha}$ ) to raise the $\mathrm{pH}$ to 6.5-7.0. Four winter cover crops - crimson clover (Trifolium incarnatum L.), rye (Secale cereale L.), hairy vetch (Vicia villosa Roth), and Austrian winter peas (Pisum sativum), were planted each on separate plots in the fall (October/November) of 
2007 and 2008 at seeding rates of 23, 85, 40 and $62 \mathrm{~kg} / \mathrm{ha}$ respectively. In the following spring, the cover crops were mowed and their residue was left on the soil surface to minimize weed emergence. The experiments were part of a study to assess the effects of cover crops on soil health, weeds, diseases and cash crop yield.

\subsubsection{Experiment 1. Effect of Cover Crop}

After the four cover crop plots including a fallow control were mowed in late spring (May) seedlings of tomato cultivar 'Amelia' obtained from Auburn University's organic production project were planted in each cover crop plot on no-till small subplots measuring $3 \mathrm{~m}$ wide by $3.6 \mathrm{~m}$ long. There were three rows of tomato per plot with plants arranged at a spacing of $45 \mathrm{~cm}$ within row and $1.2 \mathrm{~m}$ between rows with a total of 15 plants per plot. Tomato transplants were initially mulched with cotton gin trash (Table 1) to enhance weed suppression and facilitate seedling establishment. All plants were fertilized with poultry litter at $67 \mathrm{~kg} \mathrm{~N} / \mathrm{ha}$ and with Multibloom ${ }^{\circledR}$ (Hydrolysate Company of America, Isola, MS) and Daniels ${ }^{\circledR}$ Pinnacle 3-1-1 Organic fertilizer Pinnacle ${ }^{\circledR}$ (Daniels AgroSciences, East Greenwich, RI) which provided $135 \mathrm{~kg} \mathrm{~N} / \mathrm{ha}$ through drip irrigation. Tomato plants were supported with $1.2 \mathrm{~m}$ wooden stakes and tie twine. Subsequent weed control was done manually around plants or by mowing between crop rows. Tomato hornworm and other insect pests were controlled with Bacillus thuringiensis (Dipel) and Neem oil sprays, respectively. The experimental design was a randomized complete block with three replications. The replications were bordered by 5 foot wide strips of farmscape plants which included Mexican sunflower (Tithonia diversifolia), Cleome (Cleome hassleriana), Calendula (Calendula officinalis) and Buckwheat (Fagopyrum esculentum). The purpose of the farmscape plants was to attract beneficial insects such as predators and pollinators and/or to repel insect pests. These farmscape plants were an integral part of the production system and did not constitute an experimental treatment.

Table 1. Selected mineral nutrient composition of composted cotton gin trash and spent mushroom compost used in the study

\begin{tabular}{|c|c|c|c|c|c|c|c|c|}
\hline Compost & $\mathrm{Mg}$ & $\mathrm{Mn}$ & $\mathrm{Cu}$ & $\mathrm{Zn}$ & $\mathrm{Ca}$ & $\mathrm{P}$ & $\mathrm{K}$ & $\mathrm{Fe}$ \\
\hline & \multicolumn{4}{|c|}{ - } & \multicolumn{4}{|c|}{ - } \\
\hline $\mathrm{SMC}^{*}$ & 840 & 217 & 172 & 189 & 20.18 & 4.81 & 0.2 & 0.98 \\
\hline Cotton gin trash & 882 & 622 & 16 & 88 & 12.05 & 3.38 & 8.64 & 5.08 \\
\hline
\end{tabular}

*Spent mushroom compost.

\subsubsection{Experiment 2. Effect of Polyethylene Mulch and Biofungicides}

Planting beds (raised soil beds) were prepared as described above. The experiment was set up in a split-plot design with four replications. Reflective silver plastic mulch and no-mulch (bare soil) control were the main plot treatments while the four biofungicides constituted the sub-plot treatments. Both main and subplot treatments were randomly assigned such that half of the planting beds in the main plot were control and half were covered with the plastic mulch. For each sub-plot treatment, two beds (rows of tomato) about $2.25 \mathrm{~m}$ long were planted. Drip irrigation lines were laid on the beds followed by the plastic mulch. Holes about $10 \mathrm{~cm}$ wide and $8 \mathrm{~cm}$ deep were punched through the plastic or directly into the soil bed (control) for placing tomato seedling transplants. Four biofungicide treatments which consisted of spent mushroom compost (SMC) (Table 1), Plant Guardian ${ }^{\circledR}$ (PG) containing Bacillus subtilis strain QST 713 at $7.3 \times 10^{9} \mathrm{cfu} / \mathrm{g}$, Root Guardian ${ }^{\circledR}$ (RG) containing Trichoderma harzianum Rifai strain KRL-AG2 at $1 \times 10^{7} \mathrm{cfu} / \mathrm{g}$ and a control (distilled water) were applied to plants in each main plot as subplot treatments. Plant Guardian was sprayed on the stem and foliage till run-off, while Root Guardian ${ }^{\circledR}$ was applied at a rate of $250 \mathrm{ml}$ per plant on soil around each plant only. Spent mushroom compost was spread in a $7.5 \mathrm{~cm}$ radius around each plant at a rate of $1 \mathrm{~L}$ per plant. PG and RG were obtained from Gardens Alive, Lawrenceburg, IN and SMC was obtained from Quincy Farms Organic Products, Quincy, FL. All biofungicide treatments were applied only once. The control plots were manually weeded twice at 2 week intervals after planting to avoid bias on treatment effects. No additional insect pest control was carried out in this experiment due to use of reflective plastic mulch. All plants were fertilized with poultry litter at $67 \mathrm{~kg}$ N/ha and with Multibloom ${ }^{\circledR}$ (Hydrolysate Company of America, Isola, MS) and Daniels ${ }^{\circledR}$ Pinnacle 3-1-1 Organic fertilizer Pinnacle ${ }^{\circledR}$ (Daniels AgroSciences, East Greenwich, RI) which provided $135 \mathrm{~kg}$ N/ha through drip irrigation. Tomato plants were supported with $1.2 \mathrm{~m}$ wooden stakes and tie twine as described earlier. 


\subsection{Data Collection and Analyses}

Tomato diseases (including tomato spotted wilt virus [TSWV], southern blight [Sclerotium rolfsii], bacterial spot [Xanthomonas campestris pv campestris], white mold [Cladosporium fulvum], early blight [Alternaria solani], late blight [Phytophthora infestans], septoria leaf spot [Septoria lycopersici], etc.) were monitored weekly. Disease incidence (\% of diseased plants out of total observed) and disease severity (assessed using a score of 0-5 where $0=$ no disease and $5=81 \%-100 \%$ symptomatic foliage/fruit or dead plant) were measured during crop growth. Tomato fruit yields (weight, number of fruits/plant) were determined at harvest. Marketable yield was assessed by fruit size and quality. Marketable fruits were characterized as ripe blemish-free fruits $>5 \mathrm{~cm}$ in diameter and weighing more than $50 \mathrm{~g}$. All data were analyzed using ANOVA procedure in SAS (SAS, 2006) and treatment means were separated using Tukey's HSD test at $\mathrm{p}=5 \%$.

\section{Results}

In 2008, rainfall increased progressively from May to October whereas in 2009, the pattern was highly fluctuating during the same period (Figure 1A). Mean daily temperature and relative humidity ranged from $22{ }^{\circ} \mathrm{C}$ to $27{ }^{\circ} \mathrm{C}$ and from $70 \%$ to $81 \%$ respectively and their magnitudes were similar (Figures 1A and 1B) during the two cash-crop growing seasons.
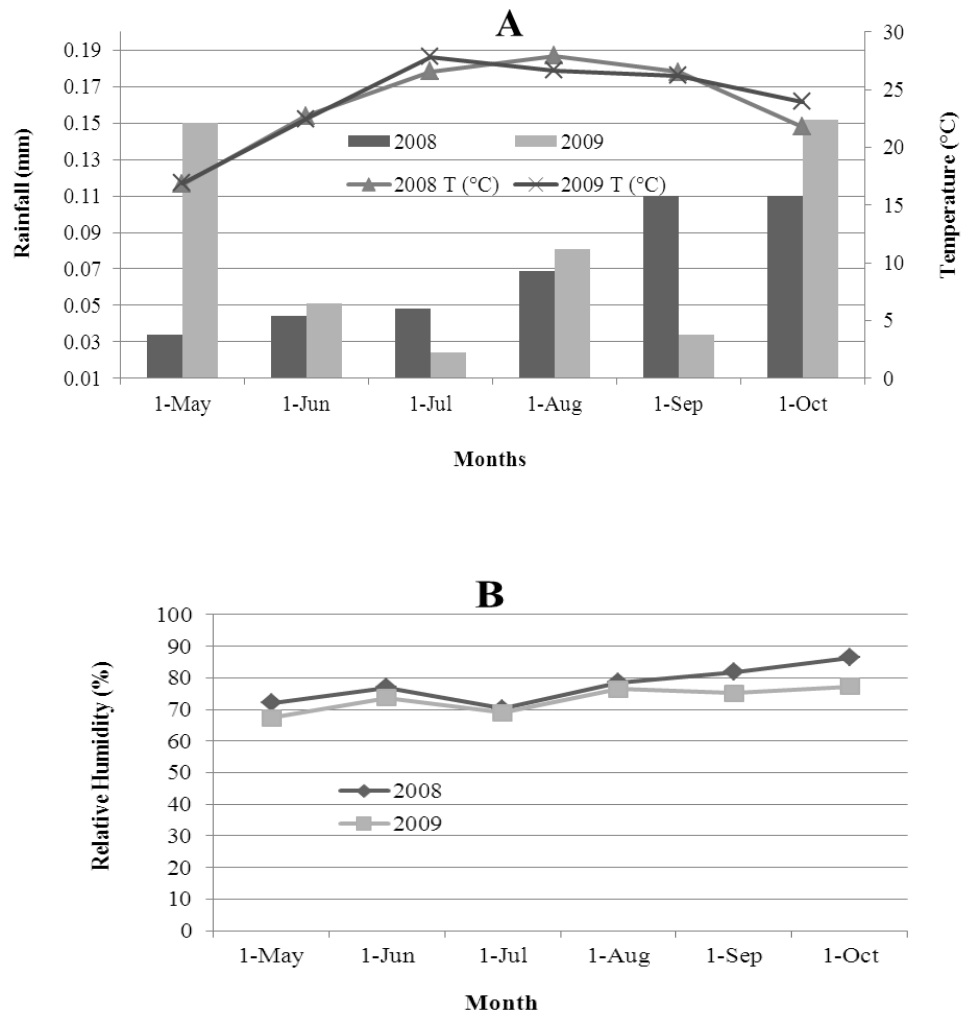

Figure 1. Rainfall, mean air temperature (A) and relative humidity (B) data calculated at one-month intervals were obtained from weather data collected at the Eddy Covariance Flux Station at the experimental site (WTARS) from May to October during the 2008 and 2009 growing seasons

\subsection{Cover Crop Effects on Weeds, Diseases and Yield}

The cover crops crimson clover, rye, hairy vetch and Austrian winter peas averaged 5.8, 7.4, 3.4, and 2.7 t/ha in biomass production (Figure 2A). In 2008 and 2009, cover crops crimson clover and rye produced high amounts of biomass (Figure 2A). All cover crops significantly reduced weed biomass compared to fallow control (Figure 2B). There were differences between the cover crops in weed suppression however, the differences were not significant. Of the four cover crops, hairy vetch and Austrian winter pea cover crop plots showed relatively lower tomato fruit rot disease incidences which were significantly lower than in the fallow plot (Figure 2C). Tomato fruit yield including number of fruits/plant from hairy vetch plots were the highest and significantly better than 
those from the fallow plots (Figures 2D and 2E).
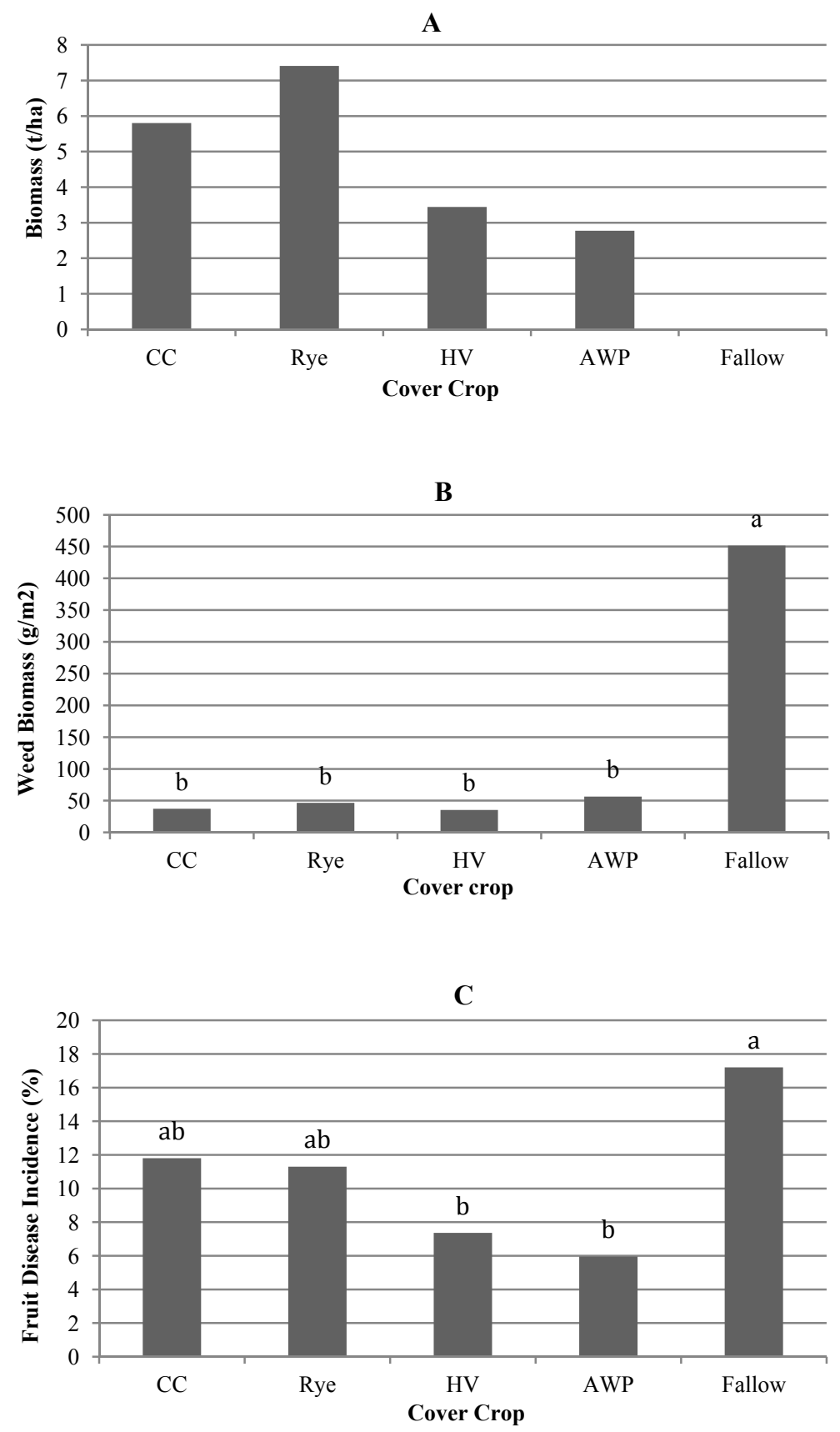
D

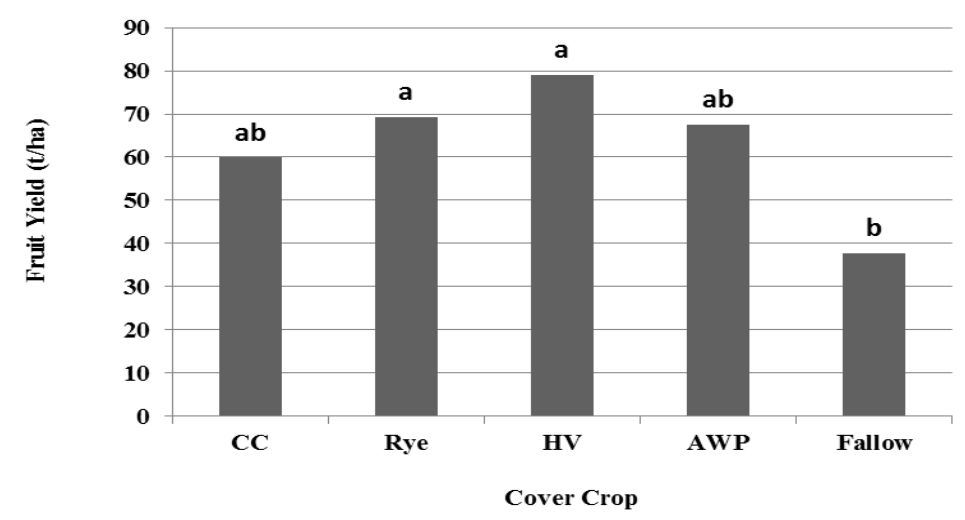

$\mathbf{E}$

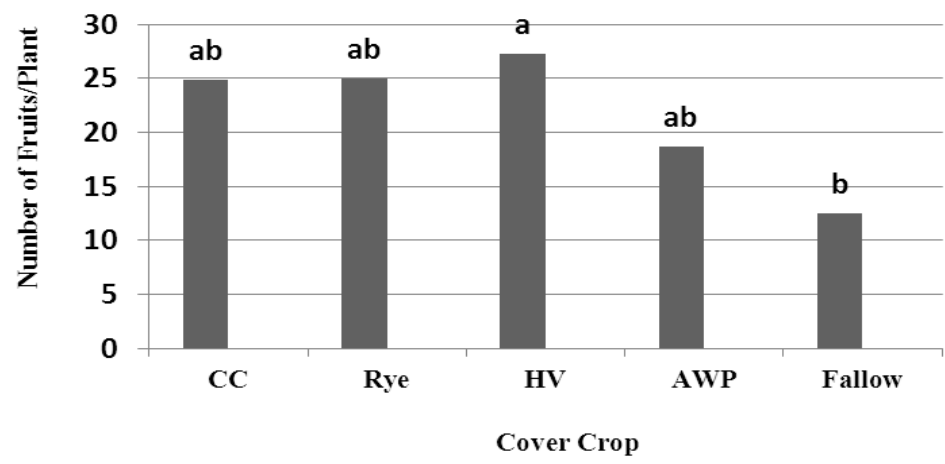

Figure 2. Biomass of winter cover crops crimson clover (CC), rye, hairy vetch (HV), Austrian winter peas (AWP) and Fallow (A), their effects on weed biomass (B), tomato fruit rot disease incidence (C), tomato fruit yield (D) and number of fruits/plant (E) in organic tomato production system during the 2009 growing season

\subsection{Effect of Plastic Mulch}

In both growing seasons, plastic mulch was significantly better than no mulch for plant height, fruit yield and number of fruits per plant (Table 2). Among the diseases observed, bacterial leaf spot was significantly more severe in the mulch treatment than control in 2008, but such trend was not observed in 2009. In 2009 however, there was a high incidence of white mold (C. fulvum) irrespective of mulch or biofungicide treatment (Table 2). Visual observations of plants indicated greater insect damage to fruits in 2009 and tended to be higher in the mulch treatment than in the control. 
Table 2. Effect of reflective plastic mulch and no-mulch (control) treatments on plant growth, fruit yield and disease severity in organic tomato in 2008 and 2009 growing seasons

\begin{tabular}{lllll}
\hline Parameter & RPM (2008) & Control (2008) & RPM (2009) & Control (2009) \\
\hline Plant height (cm) & $69.5 \mathrm{a}^{\#}$ & $64.2 \mathrm{~b}$ & $137.0 \mathrm{a}$ & $113.5 \mathrm{~b}$ \\
Total fruit yield (Mg/ha) & $39.9 \mathrm{a}$ & $30.6 \mathrm{~b}$ & $3.3 \mathrm{a}$ & $1.6 \mathrm{~b}$ \\
Total number of fruits/plant & $10.5 \mathrm{a}$ & $7.6 \mathrm{~b}$ & $4.7 \mathrm{a}$ & $2.6 \mathrm{~b}$ \\
Bacterial spot severity* & $1.4 \mathrm{a}$ & $0.7 \mathrm{~b}$ & $\mathrm{~ns}$ & $\mathrm{~ns}$ \\
Insect damage to fruits & $\mathrm{nd}$ & $\mathrm{nd}$ & $1.9 \mathrm{a}$ & $0.5 \mathrm{~b}$ \\
White mold severity & $\mathrm{ns}$ & $\mathrm{ns}$ & $3.8 \mathrm{a}$ & $3.6 \mathrm{a}$ \\
\hline
\end{tabular}

${ }^{\#}$ Means in the same row for the same year having the same letter are not significantly different according to Tukey's HSD Test at $\mathrm{p}=0.05$.

"Disease severity was assessed using a score of $0-5$, where $0=$ no disease, healthy plant; $1=1-20 \%$ symptomatic foliage; $2=21-40 \%$ symptomatic foliage; $3=41-60 \%$ symptomatic foliage; $4=61-80 \%$ symptomatic foliage and $5=81-100$ symptomatic foliage or dead plant.

ns = no symptoms;

nd $=$ not determined;

$\mathrm{RPM}=$ Reflective plastic mulch .

Reflective plastic mulch significantly improved plant height, total fruit yield and number of fruits/plant compared to the no-mulch control treatment in both growing seasons.

\subsection{Effect of Biofungicides}

Spent mushroom compost (Table 1) used as a biofungicide and applied as a sub treatment under mulch, had an enhancing effect on fruit yield in both growing seasons (Figures 3A and 3B). In 2008, SMC increased total and marketable tomato fruit yields by $29 \%$ and $34.7 \%$ respectively over the control. In 2009 , SMC significantly increased the number of fruits/plant by $61.7 \%$ and total fruit yield by $56.5 \%$ compared to the control. However the fruit yield for 2009 was remarkably lower compared to 2008 and as such the marketable yield component of the harvest for 2009 was not assessed. As observed with the mulch treatment, SMC treated plants also showed bacterial spot disease symptoms in 2008 growing season, even though tomato fruit yield increased in this treatment. Tomato yields were lower in 2009 due mainly to weather conditions when white mold disease infestation and fruit worm damage were considerably high. The biofungicides Plant Guardian (PG) did not protect the tomato plants from white mold and bacterial spot diseases (Figure 4) even though it is labelled to be effective against bacterial spot disease. 
A
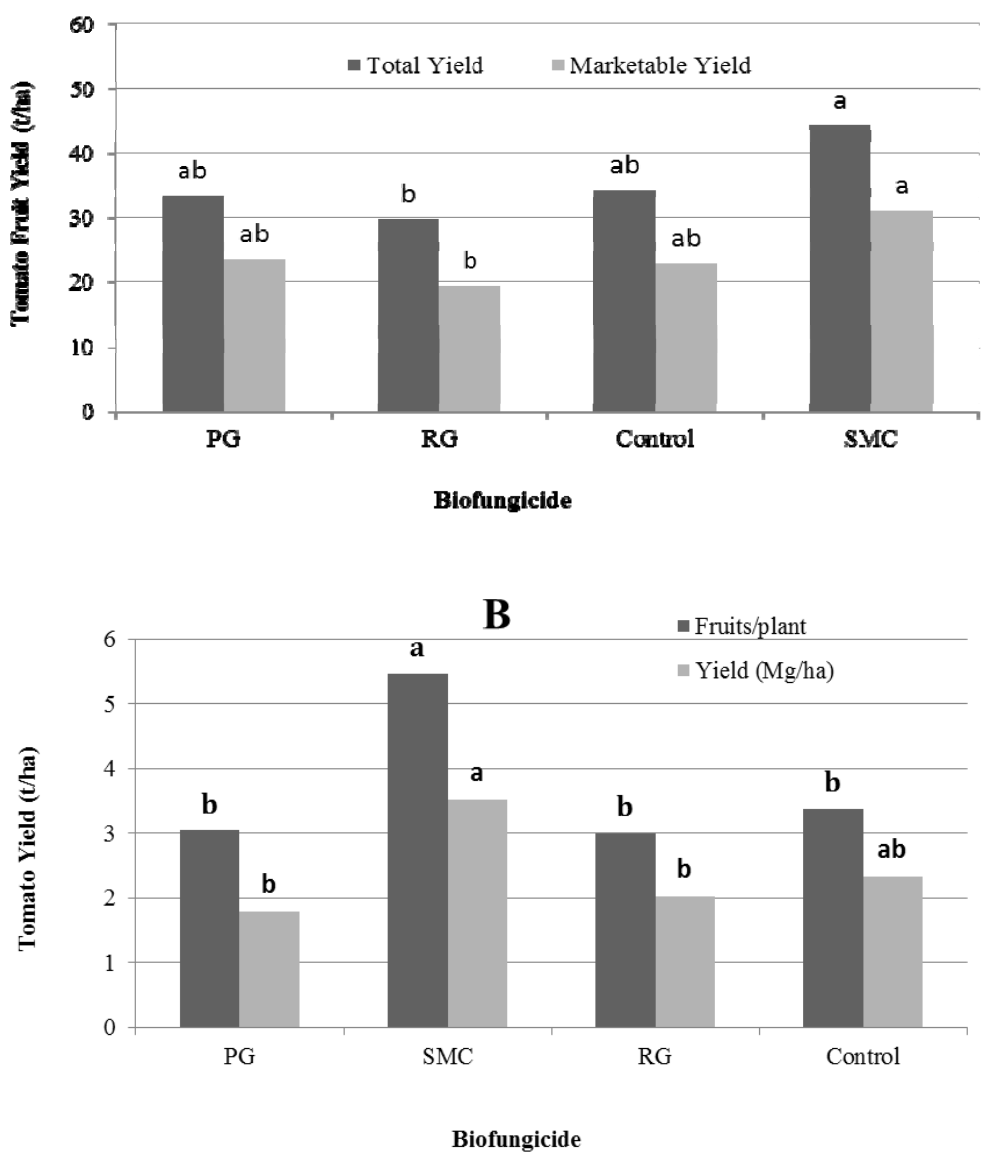

Figure 3. Effect of the biofungicides Plant Guardian (PG), Root Guardian (RG), Spent Mushroom Compost (SMC) and Control on tomato fruit yield and number of fruits/plant during the 2008 (A) and 2009 (B) growing seasons (center)

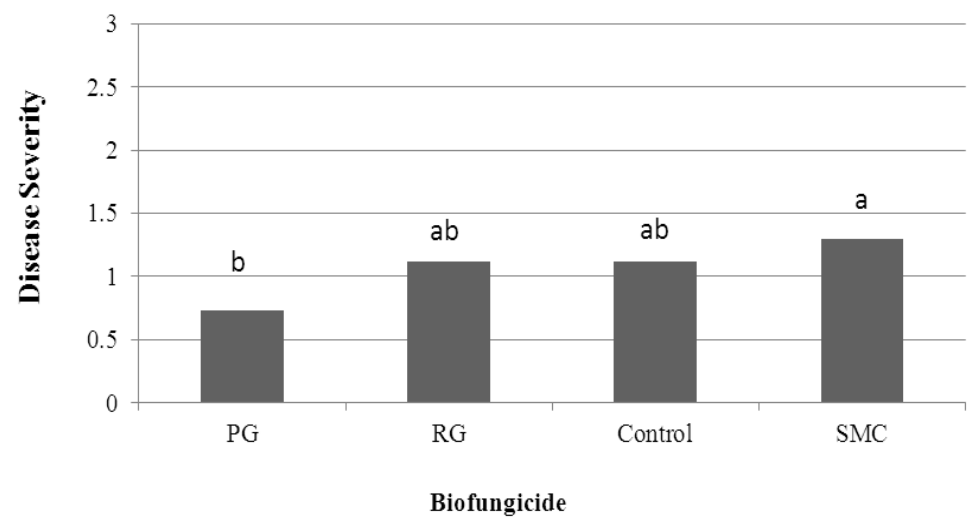

Figure 4. Effect of the biofungicides Plant Guardian (PG), Root Guardian (RG), Spent Mushroom Compost (SMC) and Control on bacterial spot disease severity during the 2008 growing season

\section{Discussion}

This research was conducted to develop cultural methods that improve weed and disease management and enhance cash crop productivity and long-term farm sustainability of small organic farms. The goal of this study was to assess the applicability of winter cover crops and polyethylene soil bed covers combined with biofungicides for managing diseases and weeds in an organic tomato production system. 
Although hairy vetch and Austrian winter peas had the least biomass due to their generally slow growth in cold weather, they were competent in suppressing weeds just as crimson clover and rye mainly due to their ability to regain rapid growth rate in the spring. Rye, which had the highest biomass in this study, is a crop that quickly establishes in the fall compared to the legumes. However, the ability of the legumes to suppress weeds even at low cover crop density may suggest that other factors may be involved. Phatak and Diaz-Perez (2007) indicated that planting tomatoes into killed hairy vetch cover crop achieved disease suppression. These cover crop plant surfaces may support a healthy population of plant surface microflora such as epiphytic bacteria which promote their disease suppressing ability. Furthermore, hairy vetch and Austrian winter peas which were observed to significantly reduce tomato fruit rot incidence, are high sources of nitrogen and can generate 41-68 to $91 \mathrm{~kg}$ of N, respectively. They also increase the population of soil organisms (Phatak et al., 1995), which may increase plant resistance to disease.

Plastic mulch and biofungicide treatment such as SMC that favored high tomato biomass (vegetative growth and fruit yield) production were also more prone to diseases and insect pest damage. Our results indicate that while reflective plastic mulch effectively suppresses weeds, it was ineffective in suppressing Cladosporium fulvum and tomato fruit worm attacks. The mulch however, played a significant role in enhancing tomato growth and fruit yield. The higher amount of rainfall recorded in 2008 growing season appeared to have contributed to bacterial spot severity the spread of which is usually influenced by rainfall or sprinkler irrigation water splashes in the field. On the contrary, the lower amount of rainfall in 2009 coupled with other environmental (wind currents, warm temperatures) and epidemiological (infected seedlings) factors, might have been favorable to C. fulvum development. SMC which was applied as a biofungicide/biopesticide in this study is a byproduct of mushroom production. After a few flushes (cycles) of mushroom have been harvested, production significantly declines. The spent substrate can then be composted and amended for various uses including being sources of enzymes due to presence of microorganisms (Ribas, de Mendonca, Camelini, \& Soares, 2009). This makes SMC suitable as biofungicides for managing plant diseases in organic production system.

The reduction in disease and insect damage observed in the control plots could be attributed to the weeds which might have shielded the crop plants but also led to reduced crop growth and fruit production. UV-reflective silver-coated plastic mulch is increasingly being used for control of Thrips which vector tomato spotted wilt virus (TSWV) disease in tomato (Momol, Olsen, Funderburk, Stavisky, \& Marois, 2004). Recently, Murphy et al. (2009) observed that reflective silver plastic mulch reduced watermelon mosaic virus incidence and yield losses in squash.

Polyethylene mulch enhanced tomato growth and fruit yield in addition to weed control, however, plants in the mulch treatments were more susceptible to leaf mold and tomato fruit worm damage compared to no mulch (control) treatment. Bicolor polyethylene mulch was successfully used to reduce infection of late blight (Phytophthora infestans) in tomato in the greenhouse (Shtienberg et al., 2010). However, relying on polyethylene mulch alone to control tomato diseases in the field may give variable results. For example, Shtienberg et al., (2010) observed that mulch was less effective in suppressing downy mildew in cucumber than $P$. infestans in tomato. Traditionally, vegetable farmers use plastic mulch to control weeds, reduce soil erosion and conserve soil moisture and buffer temperature extremes for plant growth. Modification of the plant microclimate by polyethylene mulch may not be detrimental to the development of some foliar pathogens of tomato.

\section{Conclusion}

The study showed that the winter cover crops hairy vetch, Austrian winter peas, rye and crimson clover may help manage plant diseases such as fruit rots in organic tomato production system. In addition, rye and hairy vetch cover crops significantly increased tomato fruit yield compared to the control (fallow). However, reflective polyethylene mulch and spent mushroom compost which enhanced tomato growth, fruit yield and weed suppression in organic tomato production system did not suppress tomato diseases in this study.

\section{Acknowledgements}

We are grateful to Lewis Bingham for assisting in land preparation, irrigation and other field operations. The research was supported by EPA grant \# X8-96476707 and USDA grant \# 2007-51106-18226.

\section{References}

Baldwin, K., \& Creamer, N. (2006). Cover crops for organic farms. North Carolina Cooperative Extension Service Publication No. \# E06-45788. Retrieved from http://www.cefs.ncsu.edu/resources/organicproductionguide/covercropsfinaljan2009.pdf 
Campiglia, E., Paolini, R., Colla, G., \& Mancinelli, R. (2009). The effects of cover cropping on yield and weed control of potato in a transitional system. Field Crops Research, 112, 16-23. http://dx.doi.org/10.1016/j.fcr.2009.01.010

Dabney, S. M., Delgado, J. A., \& Reeves, D. W. (2001). Using winter cover crops to improve soil and water quality. Commun. Soil Sci. Plant Anal., 32, 1221-1250. http://dx.doi.org/10.1081/CSS-100104110

Elad, Y. (2000). Changes in disease epidemics on greenhouse grown crops. Acta Hort., 534, 213-220.

Ezziyyani, M., Requena, M. E., Egea-Gilbert, C., \& Candela, M. E. (2007). Biological control of Phytophthora root rot of pepper using Trichoderma harzianum and Streptomyces rochei in combination. Journal of Phytopathology, 155, 342-349. http://dx.doi.org/10.1111/j.1439-0434.2007.01237.x

Jacobsen, B. J., Zidack, N. K., \& Larson, B. J. (2004). The nature and application of biocontrol microbes: Bacillus spp. - The role of Bacillus-based biological control agents in integrated pest management systems. Phytopathology, 94, 1272-1275. http://dx.doi.org/10.1094/PHYTO.2004.94.11.1272

Kelley, M. J. (2009). Effects of color to deter thrips and reducing the incidence of tomato spotted wilt virus (p. 81, MS Thesis, Auburn University, Auburn, AL).

Kuo, S., Sainju, U. M., \& Jellum, E. J. (1997). Winter cover cropping influence on nitrogen in soil. Soil Sc. Soc. Am. J., 61, 145-152. http://dx.doi.org/10.2136/sssaj1997.03615995006100050016x

Larkin, R. P., Griffin, T. S., \& Honeycutt, C. W. (2006). Effect of fall cover crop and different 2-year rotations on soilborne diseases and soil microbial communities. Northeast Potato Technology Forum.

Mendes, I. C., Bandick, A. K., Dick, R. P., \& Bottomley, P. J. (1999). Microbial biomass and activities in soil aggregates affected by winter cover crops. Soil Sci. Soc. Am. J., 63, 873-881. http://dx.doi.org/10.2136/sssaj1999.634873x

Momol, M. T., Olsen, S. M., Funderburk, J. E., Stavisky, J., \& Marois, J. J. (2004). Integrated management of tomato spotted wilt on field-grown tomatoes. Plant Disease, 88, 882-890. http://dx.doi.org/10.1094/PDIS.2004.88.8.882

Murphy, J. F., Eubanks, M. D., \& Masiri, J. (2009). Reflective plastic mulch but not a resistance-inducing treatment reduced watermelon mosaic virus incidence and yield losses in squash. International $J$. of Vegetable Sci., 15, 3-12. http://dx.doi.org/10.1080/19315260802446351

Nyochembeng, L. M., Mankolo, R. N., \& Mentreddy, S. R. (2010). Organic and polyethylene mulches with biofungicides for managing diseases in organic tomato production system. Phytopathology, 100, S91.

Phatak, S. C., Sumner, D. R., Chalfant, R. B., Gay, J. D., Chandler, L. D., Bugg, R. L., \& Brunson, K. E. (1995). Cover crops and pest management. HortScience, 30, 429.

Phatak, S. C., \& Díaz-Pérez, J. C. (2007). Managing pests with cover crops. In A. Clark, (Ed.), Managing Cover Crops Profitably (3rd ed.). Sustainable Agriculture Network, Beltsville, MD.

Reeves, D. W. (1997). The role of soil organic matter in maintaining soil quality in continuous cropping systems. Soil Tillage Res., 43, 131-167. http://dx.doi.org/10.1016/S0167-1987(97)00038-X

Ribas, L. C. C., de Mendonca, M. M, Camelini, C. M., \&. Soares, C. H. L. (2009). Use of spent mushroom substrates from Agaricus subufescens (syn. A. blazei, A. brasiliensis) and Lentinula edodes productions in the enrichment of a soil-based potting media for lettuce (Lactuca sativa) cultivation: Growth promotion and $\begin{array}{lllll}\text { soil } \quad \text { bioremediation. } & \text { Bioresource }\end{array}$ http://dx.doi.org/10.1016/j.biortech.2008.10.059

Rothrock, C. S., Kirkpatrick, T. L., Frans, R. E., \& Scott, H. D. (1995). The influence of winter legume cover crops on soilborne plant pathogens and cotton seedling disease. Plant Disease, 79, 167-171. http://dx.doi.org/10.1094/PD-79-0167

SAS. (1996). Statistical Analysis Software User's Guide: Statistics. SAS Institute, Cary, NC.

Sainju, U. M., Whitehead, W. F., \& Singh, B. P. (2005). Biculture legume-cereal cover crops for enhanced biomass yield and carbon and nitrogen. Agron. J., 97, 1403-1412. http://dx.doi.org/10.2134/agronj2004.0274

Shtienberg, D., Elad, Y., Bornstein, M., Ziv, G., Grava, A., \& Cohen, S. (2010). Polyethylene mulch modifies greenhouse microclimate and reduces infection of Phytophthora infestans in tomato and Pseudoperenospora cubensis in cucumber. Phytopathology, 100, 97-104. http://dx.doi.org/10.1094/PHYTO-100-1-0097 
Tarara, M. J. (2000). Microclimate modification with plastic mulch. HortScience, 35, 169-180.

Widmer, T. L., Mitkowski, N. A., \& Abawi, G. S. (2002). Soil organic matter and management of plant parasitic nematodes. J. of Nematology, 34, 289-295.

Willer, H. (2008). Organic agriculture worldwide: Current statistics. In H. Willer, M. Y. Menzler, \& N. Sorensen (Eds.), The world of organic agriculture: Statistics and emerging trends (pp. 23-46). IFOAM, Bonn.

Wyland, L. J., Jackson, L. E., Chaney, W. E., Klonsky, K., Koike, S. T., \& Kimple, B. (1996). Winter cover crops in vegetable cropping system: Impacts on nitrate leaching, soil water, crop yield, pest and management costs. Agriculture, Ecosystem and Environment, 59, 1-17. http://dx.doi.org/10.1016/0167-8809(96)01048-1

Zehnder, G. W., Murphy, J. F., Sikora, E. J., \& Kloepper, J. (2001). Application of rhizobacteria for induced resistance. European Journal of Plant Pathology, 107, 39-50. http://dx.doi.org/10.1023/A:1008732400383

\section{Copyrights}

Copyright for this article is retained by the author(s), with first publication rights granted to the journal.

This is an open-access article distributed under the terms and conditions of the Creative Commons Attribution license (http://creativecommons.org/licenses/by/3.0/). 